\title{
Incorporation of ${ }^{3} \mathrm{H}$ and ${ }^{14} \mathrm{C}$ from $\left[6 \alpha-{ }^{3} \mathrm{H}\right] \mathrm{Penicillin} \mathrm{N}$ and $\left[10-{ }^{14} \mathrm{C}, 6 a-{ }^{3} \mathrm{H}\right]$ Penicillin $\mathrm{N}$ into Deacetoxycephalosporin $\mathrm{C}$
}

\author{
Jack E. BALDWIN* and Pushpa D. SINGH* \\ Department of Chemistry, Massachusetts Institute of Technology, Cambridge, MA 02139, U.S.A. \\ and Masaru YOSHIDA, $\dagger$ Yosuke SAWADA and Arnold L. DEMAIN \\ Department of Nutrition and Food Science, Massachusetts Institute of Technology, Cambridge, MA 02139, \\ U.S.A.
}

(Received 3 September 1979)

\begin{abstract}
1. In a cell-free system prepared by lysis of protoplasts of Cephalosporium acremonium mutant $\mathrm{M}-0198,{ }^{3} \mathrm{H}$ and ${ }^{14} \mathrm{C}$ were incorporated from singly- and doubly-labelled penicillin $\mathbf{N}$ into deacetoxycephalosporin $\mathrm{C}$. 2. The deacetoxycephalosporin $\mathrm{C}$ obtained from the above feeding experiments was converted into two different crystalline derivatives, namely $\mathrm{N}$-phthalimidodeacetoxycephalosporin $\mathrm{C}$ bisbenzhydryl ester and $N$-phthalimidodeacetoxycephalosporin C bisdicyclohexylamine salt and recrystallized to constant specific activity or constant ratio of specific activity. 3. That ${ }^{3} \mathrm{H}$ is incorporated at $\mathrm{C}-7$ in the biosynthesized deacetoxycephalosporin $\mathrm{C}$ was shown by the loss of radioactivity $(95.2 \%)$ after methoxylating the derived $N$-phthalimidodeacetoxycephalosporin $C$ bisbenzhydryl ester. 4 . Deacetoxycephalosporin $C$ was also the product of the cell-free reaction conducted in the presence of ferrous ions and ascorbic acid, as shown by two-dimensional paper electrophoresis-chromatography; these additives appreciably improved the efficiency of conversion.
\end{abstract}

Kohsaka \& Demain (1976) described a cell-free system from Cephalosporium acremonium CW-19 that converted penicillin $N$ (1) into a penicillinase-resistant cephalosporinase-sensitive material. This was shown to be deacetoxycephalosporin C (2) (Yoshida et al., 1978) by paper electrophoresis and paper and thin-layer chromatography. However, further proof was required for the above observation. Recently, it was shown that the production of cephalosporin-like material was stimulated by the addition of ascorbic acid and ferrous ions to the reaction mixture (Hook et al., 1979), components that are cofactors in mono-oxygenase and dioxygenase reactions (Turner et al., 1978). The present work was designed to confirm by radioactive incorporation experiments that deacetoxycephalosporin $\mathrm{C}$ is indeed the cell-free ring-expansion product and to determine whether this same compound is also the product formed in the presence of ascorbic acid and ferrous ions.

Abbreviation used: h.p.l.c., high-pressure liquid chromatography.

* Present address: Dyson Perrins Laboratory, University of Oxford, Oxford OX1 3QY, U.K.

† Present address: Fujisawa Pharmaceutical Co., Shinkawa-cho, Nishi Kasagai-gun, Aichi, Japan.<smiles>CC1(C)S[C@@H]2C(NC(=O)CCC[C@H]([NH3+])C(=O)[O-])C(=O)N2[C@H]1C(=O)O</smiles><smiles>CC1=C(C(=O)O)N2C(=O)[C@H](NC(=O)CCC[C@H]([NH3+])C(=O)[O-])[C@H]2SC1</smiles>

\section{Experimental}

\section{Materials}

ATP (disodium salt), pyruvate kinase and phosphoenolpyruvate (monopotassium salt) were obtained from Sigma Chemical Co., London S.W.6, U.K. Purified $\beta$-lactamase I from Bacillus cereus 569/H/9 was a gift from Professor E. P. Abraham, Sir William Dunn School of Pathology, University of Oxford, Oxford, U.K. Penicillinase was obtained from Difco, East Molesey, London, U.K. Lytic enzyme, zymolase-5000, from the culture filtrate of 
Arthobacter luteus, was from the Kirin Brewery Co., Tokyo, Japan. Deacetoxycephalosporin C (disodium salt), deacetylcephalosporin $C$ and cephalosporin C (potassium salt) were gifts from Eli Lilly \& Co., Indianapolis, IN, U.S.A. Other chemicals were obtained from BDH Chemicals, Poole, Dorset, U.K., and were AnalaR grade where possible.

H.p.l.c.-grade methanol and acetonitrile were obtained from Fisher Scientific Co., Pittsburgh, PA, U.S.A., and Rathburn Chemicals, Walkerburn, Peeblesshire, Scotland, U.K. Metal-free water and glacial acetic acid were used for h.p.l.c. separations. Penicillin N samples were synthesized as described in the preceding paper (Baldwin et al., 1980).

\section{Paper electrophoresis and chromatography}

Electrophoresis at pH6.5 was carried out on Whatman no. 1 paper at $70 \mathrm{~V} / \mathrm{cm}$ for $45 \mathrm{~min}$ in an apparatus similar to that used by Katz et al. (1959). The buffer used was that described by Corran \& Waley (1974). Paper chromatograms were run in the second dimension at $4^{\circ} \mathrm{C}$ for $18 \mathrm{~h}$ in propan1-ol/pyridine/acetic acid/acetonitrile/water (40:30: 9:40:36, by vol.) (Whitney et al., 1972). Cephalosporins were detected on the paper by spraying with ninhydrin reagent (Woiwod, 1949).

\section{Measurement of radioactivity}

The radioactivity was measured by using Beckman LS-8100 and Nuclear-Chicago Unilux 11A liquid-scintillation counters. Samples of usually $5-10 \mu \mathrm{l}$ were added to $3 \mathrm{ml}$ portions of a watermiscible scintillation fluid that consisted of toluene, 1,4-dioxan and 2-ethoxyethanol $(1: 3: 3$, by vol.) in which were dissolved $8 \%(\mathrm{w} / \mathrm{v})$ naphthalene, $1 \%$ $(w / v)$ 2,5-diphenyloxazole and $0.05 \%(w / v) ~ 1,4-b i s-$ (4-methyl-5-phenyloxazol-2-yl)benzene. The samples were cooled for $15 \mathrm{~min}$ before counting for radioactivity. The efficiency of counting was $31 \%$. To determine the distribution of ${ }^{3} \mathrm{H}$-labelled compounds after paper chromatography and electrophoresis, the paper was cut into segments $(1 \mathrm{~cm} \times 3 \mathrm{~cm})$ and each segment immersed in $3 \mathrm{ml}$ of scintillation fluid (Usher et al., 1975). The counting efficiency was $12 \%$.

A weighed amount of crystalline derivative (usually dried in vacuo for 3-4 days) after each crystallization was dissolved in $10-15 \mathrm{ml}$ of Scintiverse liquid for counting radioactivity. The counting efficiencies in these cases were $50-53 \%$ for ${ }^{3} \mathrm{H}$ and $89 \%$ for ${ }^{14} \mathrm{C}$.

\section{Fluorography}

Fluorography (Lasky \& Mills, 1975) was carried out as described by O'Sullivan et al. (1979). After 10 days spots were visible on the developed film.

\section{Antibacterial activities}

These were determined by using Escherichia coli Ess or Pseudomonas aeruginosa Pss as assay organism as described by Yoshida et al. (1978).

\section{Preparation and use of a cell-free system from C. acremonium}

A cell-free enzyme system from protoplasts of mutant M-0198 of C. acremonium was prepared as described by Yoshida et al. (1978).

\section{Incubation of cold and labelled penicillin $N$ with the enzyme system}

(1) Penicillin $\mathrm{N}(1.57 \mu \mathrm{mol})$ was added to $20 \mathrm{ml}$ of cell-free extract in four $5 \mathrm{ml}$ batches in the presence of $25 \mu \mathrm{mol}$ of ATP, $50 \mu \mathrm{mol}$ of phosphoenolpyruvate and $500 \mu \mathrm{g}$ of pyruvate kinase. The final $\mathrm{pH}$ of the cell-free system was adjusted to 7.2 . The mixture was incubated at $25^{\circ} \mathrm{C}$ at $250 \mathrm{rev}$. $/ \mathrm{min}$ for $5 \mathrm{~h}$.

(2) $\left[6 \alpha^{-3} \mathrm{H}\right]$ Penicillin $\mathrm{N}(1.57 \mu \mathrm{mol}$; sp. radioactivity $22.86 \mu \mathrm{Ci} / \mu \mathrm{mol}$ ) was added to $20 \mathrm{ml}$ of cell-free system in four $5 \mathrm{ml}$ batches and incubated as in (1).

(3) $\left[6 \alpha-{ }^{3} \mathrm{H}\right]$ Penicillin $\mathrm{N}(0.79 \mu \mathrm{mol}$; sp. radioactivity $24 \mu \mathrm{Ci} / \mu \mathrm{mol}$ ) was added to $15 \mathrm{ml}$ of cell-free extract in three $5 \mathrm{ml}$ batches and incubated as in (1).

(4) Doubly-labelled penicillin N $(0.52 \mu \mathrm{mol}$; sp. radioactivity of ${ }^{3} \mathrm{H}, 22.06 \mu \mathrm{Ci} / \mu \mathrm{mol}$; sp. radioactivity ${ }^{14} \mathrm{C}, 0.166 \mu \mathrm{Ci} / \mu \mathrm{mol} ;{ }^{14} \mathrm{C} /{ }^{3} \mathrm{H}, 0.75 \times 10^{-2}$ ) was added to $10 \mathrm{ml}$ of cell-free system (two $5 \mathrm{ml}$ batches) and incubated as in (1).

(5) $\left[6 \alpha-{ }^{3} \mathrm{H}\right]$ Penicillin $\mathrm{N}(26.2 \mathrm{nmol}$; sp. radioactivity $20.67 \mu \mathrm{Ci} / \mu \mathrm{mol}$ ) was added to $1 \mathrm{ml}$ of cell-free extract in the presence of $0.5 \mu \mathrm{mol}$ of ATP, $1.0 \mu \mathrm{mol}$ of phosphoenolpyruvate, $10 \mu \mathrm{g}$ of pyruvate kinase, $100 \mathrm{nmol}$ of $\mathrm{FeSO}_{4}, 7 \mathrm{H}_{2} \mathrm{O}$ and $800 \mathrm{nmol}$ of ascorbic acid. The $\mathrm{pH}$ of the reaction mixture was adjusted to 7.2 and incubated at $25^{\circ} \mathrm{C}$ at $250 \mathrm{rev} . / \mathrm{min}$ for $3 \mathrm{~h}$. Another $1 \mathrm{ml}$ of cell-free system was heated in a boiling-water bath for $5 \mathrm{~min}$, cooled and incubated with penicillin $\mathbf{N}$ and other additives as a control experiment.

\section{Analysis of incubation mixtures}

For expts. 1, 2, 3 and 4. A portion $(10-20 \mathrm{ml})$ of reaction mixture was treated with $75 \%(\mathrm{v} / \mathrm{v})$ methanol to precipitate protein and other large molecules. The precipitates were removed by centrifugation at $3800 \mathrm{~g}$ for $10 \mathrm{~min}$. The supernatant fluid was evaporated to dryness under reduced pressure, $10 \mathrm{ml}$ of water was added to the dried sample and the $\mathrm{pH}$ was adjusted to 3-4 with $\mathrm{H}_{2} \mathrm{SO}_{4}$. Amberlite XAD-2 polymeric adsorbent (2 $\mathrm{g}$; gift from Smith, Kline and French) was suspended in $50 \%(\mathrm{v} / \mathrm{v})$ methanol and transferred to a glass column $(0.5 \mathrm{~cm} \times 30 \mathrm{~cm})$. The column was successively 
washed with $1 \mathrm{M}-\mathrm{NaOH}, 0.5 \mathrm{M}-\mathrm{H}_{2} \mathrm{SO}_{4}$ and water until the $\mathrm{pH}$ of the effluent was 3.0. The sample solution was applied to the column, which was eluted with $10 \mathrm{ml}$ of $10 \%(\mathrm{v} / \mathrm{v})$ propan-2-ol; $2 \mathrm{ml}$ fractions were collected. The fractions containing $\beta$-lactam antibiotics were detected by assay with $P$. aeruginosa Pss; those containing penicillin $\mathrm{N}$ or a cephalosporin were pooled and concentrated under reduced pressure.

The residue was dissolved in a minimum amount of water, filtered through a millipore filter and purified by h.p.l.c. (Miller \& Neuss, 1976). All chromatograms were obtained by using a Waters M-6000 pump, U6K septumless injector and a $254 \mathrm{~nm}$ u.v. detector (Waters Associates, Milford, MA, U.S.A.). The stationary phase was bondedphase propylamine on $10 \mu \mathrm{m}$ silica (Waters Associates; $4 \mathrm{~mm}$ internal diam. $\times 30 \mathrm{~cm}$ ). The solvent system used was glacial acetic acid/methanol/acetonitrile/deionized water $(2: 4: 7.5: 86.5$, by vol.). Separations were done at $11730-14490 \mathrm{kPa}$ with a flow rate of $2 \mathrm{ml} / \mathrm{min}$ and a chart speed of 0.5 in $/ \mathrm{min}$. Three fractions were collected as shown in Fig. 2 and evaporated to dryness (high vacuum, $25^{\circ} \mathrm{C}$ ). The residues were dissolved in $200 \mu \mathrm{l}$ of water and bioactivities were measured. The radioactive content was determined in the case of radioactive experiments. Incubation mixtures (1)-(5) were analysed as follows. (1) The product from feeding unlabelled penicillin $\mathbf{N}$ was purified by h.p.l.c. as described above and co-eluted with authentic deacetoxycephalosporin C. (2) Fraction (A) was diluted with $124.6 \mu \mathrm{mol}$ of deacetoxycephalosporin $\mathbf{C}$ disodium salt and converted into $N$-phthalimidodeacetoxycephalosporin C bisbenz- hydryl ester (3) (Fechtig et al., 1968). The crude product was purified by preparative t.l.c. on silica with benzene/ethyl acetate $(4: 1, v / v)$ as eluent and recrystallized from absolute ethanol. (3) Fraction (A) was diluted with $124.6 \mu \mathrm{mol}$ of deacetoxycephalosporin $\mathrm{C}$ disodium salt and converted into $\mathrm{N}$-phthalimidodeacetoxycephalosporin $\mathrm{C}$ bisdicyclohexylamine salt (4) and recrystallized from absolute ethanol. (4) Fraction (A) from the doublylabelled experiment was treated as in (1). (5) The reaction mixtures from the native and boiled cell-free systems from incubation (5) were precipitated with $75 \%(\mathrm{v} / \mathrm{v})$ methanol and centrifuged at $2500 \mathrm{~g}$ for $10 \mathrm{~min}$. The supernatants were freeze-dried after removal of methanol, the residues dissolved in $1.4 \mathrm{ml}$ of water, filtered, $49.8 \mu \mathrm{mol}$ each of deacetoxycephalosporin $\mathrm{C}$, deacetylcephalosporin $\mathrm{C}$ and cephalosporin $\mathrm{C}$ were added and the products were purified by h.p.l.c. as described previously. The fractions corresponding to the various cephalosporins were collected and the remainder were pooled. All the fractions were evaporated to dryness under high vacuum at $25^{\circ} \mathrm{C}$. The cephalosporin fractions were dissolved in $100 \mu \mathrm{l}$ of water and the pool was dissolved in $200 \mu$ l of water; $10 \mu \mathrm{l}$ was used for radioactive measurement. The remainder was freeze-dried and analysed by two-dimensional paper electrophoresis-chromatography. (6) Synthetic [ $7 \alpha$ ${ }^{3} \mathrm{H}$ ]deacetoxycephalosporin $\mathrm{C}$ monosodium salt was purified by h.p.l.c. as described before and analysed by two-dimensional paper electrophoresis-chromatography as a control. (7) The crystalline derivative $N$-phthalimidodeacetoxycephalosporin C bisbenzhydryl ester of constant specific activity was methoxylated at C-7 by the procedure described by

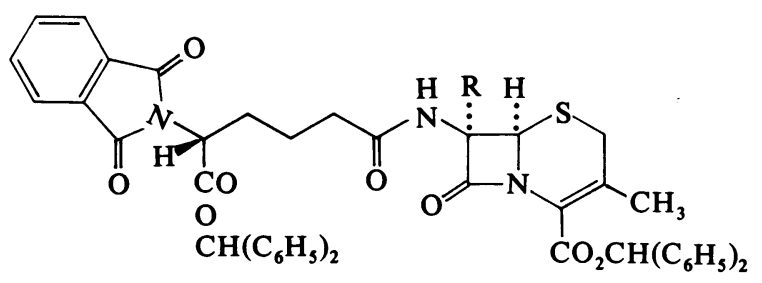

$(3 ; \mathrm{R}=\mathrm{H})$

$\left(5 ; \mathrm{R}=\mathrm{OCH}_{3}\right)$

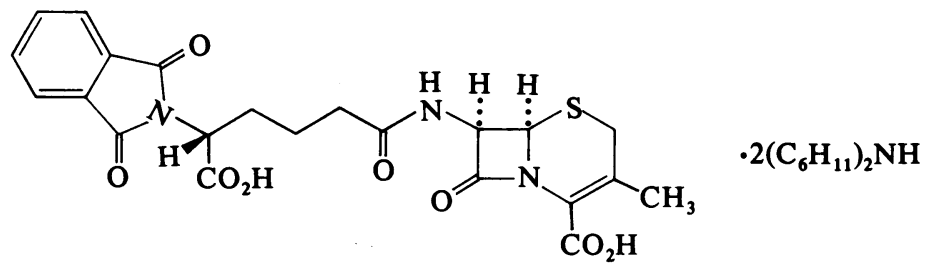

(4) 
Koppel \& Koehler (1973) and purified by preparative t.l.c. on silica with benzene/ethyl acetate $(4: 1, \mathrm{v} / \mathrm{v})$ as eluent.

\section{Results}

All penicillin $\mathbf{N}$ samples were synthesized as described in the preceding paper (Baldwin et al., 1980 ) and were $30-40 \%$ pure by bioassay on agar plates seeded with $E$. coli Ess or $P$. aeruginosa Pss (cephalosporin $\mathrm{C}$ as reference standard). This material did not contain any $\beta$-lactamase-resistant material, as seen on plates incorporating penicillinase, and had no peak in the deacetoxycephalosporin C, deacetylcephalosporin C and cephalosporin $\mathrm{C}$ region when injected through h.p.l.c. under the same conditions as those used for the analysis of the product, even at the $1 \%$ level. The crude penicillin $\mathbf{N}$ was used as such for the biosynthetic experiments.

The three cephalosporins were well separated on h.p.l.c. as shown in Fig. 1. The h.p.l.c. profile of the product obtained by feeding unlabelled penicillin $\mathbf{N}$ had a peak in the deacetoxycephalosporin $\mathrm{C}$ region

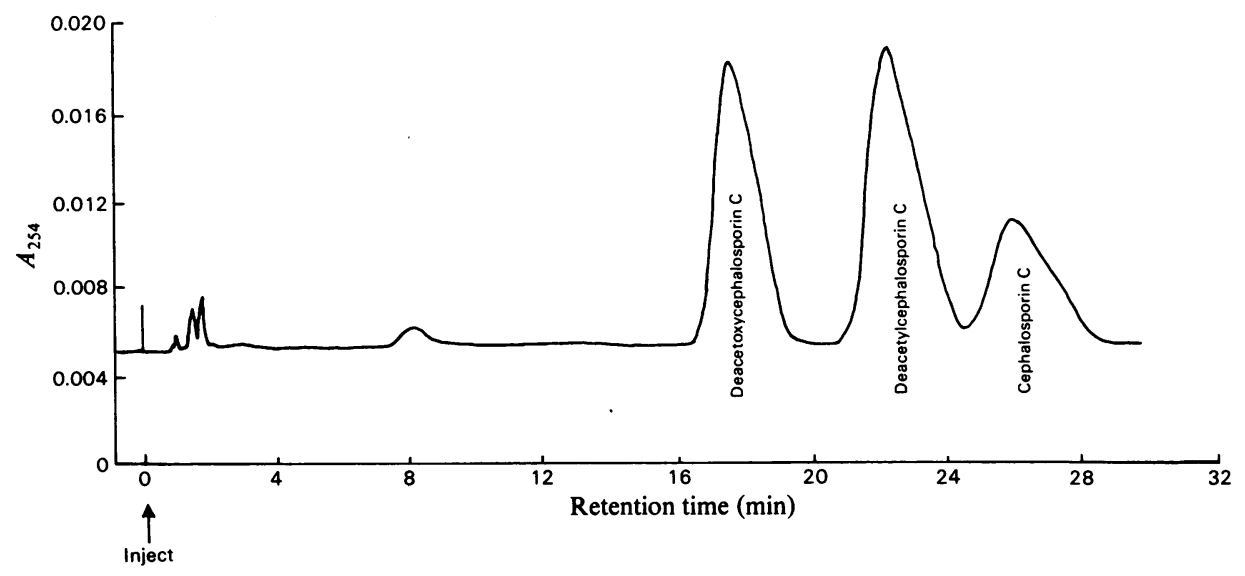

Fig. 1. Separation of deacetoxycephalosporin $C$, deacetylcephalosporin $C$ and cephalosporin $C$ (authentic samples) on h.p.l.c.

A mixture of deacetoxycephalosporin C $(5 \mu \mathrm{g})$, deacetylcephalosporin C $(5 \mu \mathrm{g})$ and cephalosporin C (5 $\mu \mathrm{g})$ was separated by h.p.l.c. The column material was bonded-phase propylamine on $10 \mu \mathrm{m}$ silica and acetic acid/methanol/ acetonitrile/water $(2: 4: 7.5: 86.5$, by vol. $)$ as solvent at a pressure of $13110 \mathrm{kPa}$.

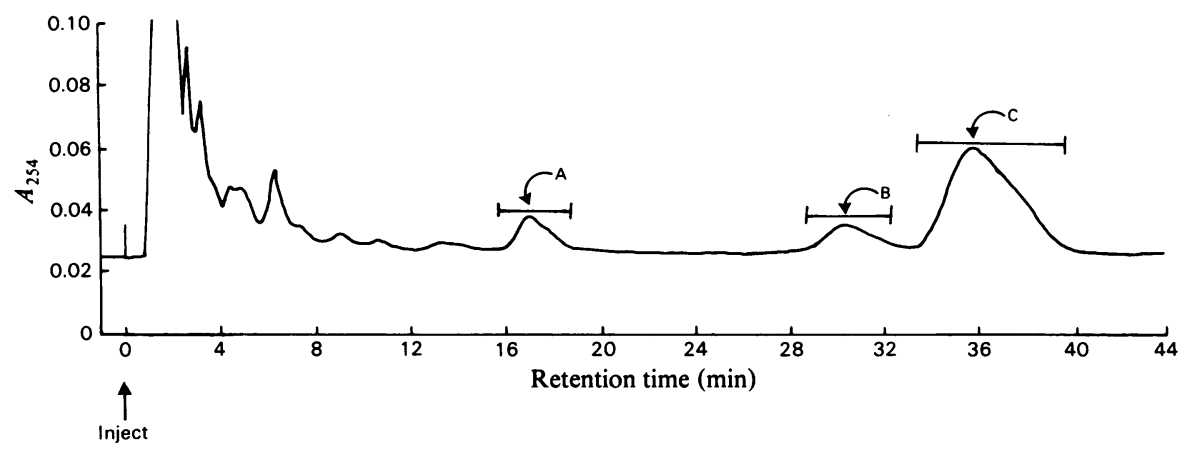

Fig. 2. Separation of the ring-expansion product obtained by feeding $\left[6 \alpha-{ }^{3} \mathrm{H}\right]$ penicillin $N$ to the cell-free extract of C. acremonium mutant $M-0198$

The product obtained by feeding penicillin $N$ to the cell-free extract was dissolved in $150 \mu \mathrm{l}$ of water and purified by h.p.l.c. in six $25 \mu \mathrm{l}$ portions. The column material was bonded-phase propylamine on $10 \mu \mathrm{m}$ silica with acetic $\mathrm{acid} / \mathrm{methanol} /$ acetonitrile/water $(2: 4: 7.5: 86.5$, by vol.) as solvent at a pressure of $13110 \mathrm{kPa}$. Fraction (A) was the fraction corresponding to deacetoxycephalosporin $\mathrm{C}$ and fractions (B) and (C) were the radioactive impurities in the penicillin $\mathrm{N}$ sample. 
that was enhanced when the incubation mixture was augmented with authentic deacetoxycephalosporin C. The results for expts. 2 and 3 are shown in Table 1. The fractions corresponding to deacetoxycephalosporin $\mathrm{C}$ were diluted with unlabelled deacetoxycephalosporin $\mathrm{C}$ and converted into $\mathrm{N}$ phthalimidodeacetoxycephalosporin $\mathrm{C}$ bisbenzhydryl ester (expt. 2) and $N$-phthalimidodeacetoxycephalosporin C bisdicyclohexylamine salt (expt. 3) and recrystallized to constant specific activity. The specific radioactivities after repeated crystallization of two different crystalline derivatives, namely $N$-phthalimidodeacetoxycephalosporin $\mathrm{C}$ bisbenzhydryl ester and $N$-phthalimidodeacetoxycephalosporin $\mathrm{C}$ bisdicyclohexylamine salt, were 3.27 and $4.50 \mu \mathrm{Ci} / \mathrm{mmol}$ respectively.

The efficiency of conversion of penicillin $\mathrm{N}$ into deacetoxycephalosporin $C$ was $16.5 \%$ and $9.1 \%$ in expts. 2 and 3 respectively (on the basis of the amount of product determined by bioassay before purification).

The radioactivities of various fractions after h.p.l.c. purification of the product from doublylabelled penicillin $\mathbf{N}$ are given in Table 2 and the specific radioactivities of ${ }^{3} \mathrm{H}$ and ${ }^{14} \mathrm{C}$, and the ${ }^{14} \mathrm{C} /{ }^{3} \mathrm{H}$ ratio of the crystalline derivative, $N$-phthalimido- deacetoxycephalosporin C bisbenzhydryl ester, were $1.69 \mu \mathrm{Ci} / \mathrm{mmol}, 1.70 \times 10^{-2} \mu \mathrm{Ci} / \mathrm{mmol}$ and $1.01 \times 10^{-2}$ respectively.

The radioactivities of various cephalosporin fractions and the pool after h.p.l.c. purification of the product obtained from the cell-free reaction in the presence of cofactors ( $\mathrm{Fe}^{2+}$ and ascorbate) are given in Table 3. The three cephalosporins were separated by two-dimensional electrophoresis-chromato-

Table 2. Radioactivities of various fractions from feeding doubly-labelled penicillin $N$ to the cell-free extract of C. acremonium mutant $M-0198$

The residues obtained after removal of solvent from various fractions after h.p.l.c. purification were dissolved in $200 \mu \mathrm{l}$ of water and radioactivities were measured as described in the Experimental section.

\begin{tabular}{ccc} 
Fraction no. & \multicolumn{2}{c}{ Total radioactivity } \\
$\overbrace{}^{3} \mathrm{H}(\mu \mathrm{Ci})$ & $10^{-2} \times{ }^{14} \mathrm{C}(\mu \mathrm{Ci})$ \\
B & 2.080 & 1.760 \\
C & 0.094 & 0.093 \\
& 1.600 & 1.440
\end{tabular}

Table 1. Radioactivities and bioactivities of various fractions obtained by feeding $\left[6 \alpha-{ }^{3} \mathrm{H}\right]$ penicillin $\mathrm{N}$ to the cell-free extract of C. acremonium mutant $M-0198$

The residues obtained after removal of solvent from various fractions after h.p.l.c. purification were dissolved in $200 \mu \mathrm{l}$ of water and the radioactivities and bioactivities were measured as described in the Experimental section.

\begin{tabular}{ccccc} 
Expt. & Fraction & Total activity & \multicolumn{2}{c}{ Total bioactivity $(\mu \mathrm{g}):$} \\
no. & no. & $(\mu \mathrm{Ci})$ & With penicillinase & Without penicillinase \\
2 & $\mathrm{~A}$ & 0.760 & 14.60 & 14.60 \\
& $\mathrm{~B}$ & 0.175 & 0.80 & 0.86 \\
& $\mathrm{C}$ & 5.900 & 3.30 & 3.00 \\
3 & $\mathrm{~A}$ & 1.820 & 13.70 & 13.80 \\
& $\mathrm{~B}$ & 3.040 & 1.30 & 1.50 \\
& $\mathrm{C}$ & 9.400 & 3.50 & 3.50
\end{tabular}

Table 3. Radioactivities of various fractions from feeding $\left[6 \alpha^{-3} \mathrm{H}\right]$ penicillin $N$ to the cell-free extract of $\mathrm{C}$. acremonium mutant M-0198 in the presence of cofactors $\left(\mathrm{Fe}^{2+}\right.$ and ascorbate)

The deacetoxycephalosporin $\mathrm{C}$, deacetylcephalosporin $\mathrm{C}$ and cephalosporin $\mathrm{C}$ fractions obtained after h.p.l.c. purification were dissolved in $100 \mu \mathrm{l}$ of water and the pool (remainder) in $200 \mu \mathrm{l}$ of water, after removal of solvent. The radioactivities of various fractions were determined as described in the Experimental section.

Fraction

Deacetoxycephalosporin C Deacetylcephalosporin C Cephalosporin C Pool
Radioactivity $(\mu \mathrm{Ci})$

\begin{tabular}{cr}
\hline Cell-free reaction & Boiled cell-free \\
0.173 & 0.033 \\
0.084 & 0.078 \\
0.032 & 0.023 \\
0.790 & 0.900
\end{tabular}


graphy. The results of fluorographic and ninhydrin spraying analysis of two-dimensional paper electrophoresis-chromatography were as follows.

\section{(a) Cell-free reaction products}

The deacetoxycephalosporin $\mathrm{C}$ fraction from the h.p.l.c. purification showed a ninhydrin-positive and radioactive spot corresponding to deacetoxycephalosporin C. The deacetylcephalosporin C fraction showed a ninhydrin-positive and non-radioactive spot corresponding to deacetylcephalosporin $C$ with two minor radioactive impurities. The cephalosporin $\mathrm{C}$ fraction had a ninhydrin-positive and non-radioactive spot corresponding to cephalosporin $\mathrm{C}$.

\section{(b) Boiled cell-free extract reaction products}

All three chromatograms had ninhydrin-positive non-radioactive spots corresponding to deacetoxycephalosporin $\mathrm{C}$, deacetylcephalosporin $\mathrm{C}$ and cephalosporin $\mathrm{C}$ with two more ninhydrin-positive non-radioactive spots. However, there was a minor radioactive spot in the deacetylcephalosporin $\mathrm{C}$ fraction that did not coincide with deacetylcephalosporin $\mathrm{C}$ and was ninhydrin-negative.

Similar two-dimensional paper electrophoresischromatographic analysis of synthetic $\left[7 \alpha^{-3} \mathrm{H}\right]$ deacetoxycephalosporin $\mathrm{C}$ showed a ninhydrin-positive radioactive spot corresponding to deacetoxycephalosporin $\mathrm{C}$ with a minor radioactive ninhydrin-negative impurity.

The $N$-phthalimidodeacetoxycephalosporin $\mathrm{C}$ bisbenzhydryl ester (sp. activity $44.43 \mathrm{nCi} / \mu \mathrm{mol}$ ) on methoxylation gave the $7 \alpha$-methoxy derivative (5) (sp. activity $2.10 \mathrm{nCi} / \mu \mathrm{mol}$ ).

Incorporation of ${ }^{3} \mathrm{H}$ from penicillin $N$ into deacetoxycephalosporin $C$

To determine the incorporation of ${ }^{3} \mathrm{H}$ into deacetoxycephalosporin $\mathrm{C}$ an experiment similar to expt. 2 was carried out simultaneously with $1.97 \mu \mathrm{mol}$ of $\left[6 \alpha^{-3} \mathrm{H}\right]$ penicillin $\mathrm{N}$ (sp. activity $28.38 \mu \mathrm{Ci} / \mu \mathrm{mol}$ ) in $20 \mathrm{ml}$ of the cell-free system, except that in this case, the amounts of product and total antibiotics were determined at the end of the incubation period. The supernatant liquid obtained after precipitation of proteins and centrifugation was freeze-dried, purified on an XAD-2 column (the same fraction numbers as for expt. 2 were collected without bioassay to minimize the loss of product) followed by h.p.l.c. purification. The deacetoxycephalosporin $\mathrm{C}$ fraction was diluted with $124.6 \mu \mathrm{mol}$ of deacetoxycephalosporin $\mathrm{C}$ disodium salt, converted into $N$-phthalimidodeacetoxycephalosporin C bisbenzhydryl ester (3), and recrystallized to constant specific activity $(44.43 \mathrm{nCi} /$ $\mu \mathrm{mol}, 120 \mu \mathrm{mol})$.
The amounts of total antibiotics and deacetoxycephalosporin $\mathrm{C}$ were $348.75 \mu \mathrm{g}$ and $72.00 \mu \mathrm{g}$ $(0.20 \mu \mathrm{mol})$ respectively. The conversion of penicillin $\mathbf{N}$ into deacetoxycephalosporin $\mathbf{C}$ corresponded to $10.1 \%$. Assuming the specific activity of deacetoxycephalosporin $\mathbf{C}$ from feeding penicillin $\mathbf{N}$ to be the same as that of starting penicillin $\mathrm{N}$, the estimated amount of deacetoxycephalosporin C formed would be $0.195 \mu \mathrm{mol}$. This would correspond to a specific activity of $27.3 \mu \mathrm{Ci} / \mu \mathrm{mol}$. Thus the estimated specific activity of the recrystallized $N$-phthalimidodeacetoxycephalosporin $\mathrm{C}$ bisbenzhydryl ester would be $42.70 \mathrm{nCi} / \mu \mathrm{mol}$, which is the same as the observed value $(44.43 \mathrm{nCi} / \mu \mathrm{mol})$ within experimental error.

\section{Discussion}

In a cell-free system prepared by lysis of protoplasts of $C$. acremonium mutant M-0198, penicillin $\mathrm{N}$ was converted into a penicillinase-resistant substance. This substance had a peak in the deacetoxycephalosporin $\mathrm{C}$ elution region on h.p.l.c. that was co-eluted with authentic deacetoxycephalosporin C after augmentation with authentic material.

$\left[6 \alpha-{ }^{3} \mathrm{H}\right]$ Penicillin $\mathrm{N}$ was converted by the cell-free system into deacetoxycephalosporin $\mathrm{C}$, which was diluted with unlabelled deacetoxycephalosporin $\mathrm{C}$ disodium salt, converted into $N$-phthalimidodeacetoxycephalosporin C bisbenzhydryl ester (3) and also $N$-phthalimidodeacetoxycephalosporin C bisdicyclohexylamine salt (4) and crystallized to constant specific radioactivity. The specific radioactivity of the formed deacetoxycephalosporin C was the same, within experimental error, as the starting penicillin $\mathbf{N}$.

The presence of ${ }^{3} \mathrm{H}$ at C-7 in deacetoxycephalosporin $\mathrm{C}$ was shown by the loss $(95.2 \%)$ of radioactivity after $7 \alpha$-methoxylation of the derived $N$-phthalimidodeacetoxycephalosporin C bisbenzhydryl ester, crystallized to constant specific radioactivity.

Feeding of doubly-labelled penicillin $\mathrm{N}$ and treatment of the cephalosporin product, as before, gave after crystallization a constant ratio of specific activity of ${ }^{14} \mathrm{C} /{ }^{3} \mathrm{H}$. The fluorographic analysis of two-dimensional paper electrophoresis-chromatography showed that deacetoxycephalosporin $\mathrm{C}$ was also the ring-expansion product in the presence of the cofactors, i.e. $\mathrm{Fe}^{2+}$ and ascorbic acid.

All these results strongly suggest that deacetoxycephalosporin $\mathrm{C}$ is the major biosynthetic product of penicillin $\mathbf{N}$ conversion in the cell-free system. That this ring expansion is an enzymic process was shown by the absence of cephalosporin formation when penicillin $\mathrm{N}$ was added to a pre-boiled cell-free system and subsequently treated in exactly the same manner. 
We thank Professor E. P. Abraham, Sir William Dunn School of Pathology, University of Oxford, Oxford, U.K., for use of his facilities, Dr. J. O'Sullivan and Mrs. Joyce Huddleston for helpful discussions and Mr. T. Beesley for technical assistance. We also thank Dr. Maxwell J. Crossley for developing the h.p.l.c. system and for running the initial separations. We acknowledge the assistance of Ms. Sheau-Ping $\mathrm{Hu}$ (University of Boston) for freeze-drying the cell-free extracts. The work of M. Y., Y. S. and A. L. D. was supported by the Bristol-Myers Company (Industrial Division).

\section{References}

Baldwin, J. E., Herchen, S. R. \& Singh, P. D. (1980) Biochem. J. 186, 881-887

Corran, P. H. \& Waley, S. G. (1974) Biochem. J. 139, $1-10$

Fechtig, B., Peter, H., Bickel, H. \& Vischer, E. (1968) Helv. Chim. Acta. 51, 1108-1119

Hook, D. J., Chang, L. T., Elander, R. P. \& Morin, R. B. (1979) Biochem. Biophys. Res. Commun. 87, 258-265
Katz, A. M., Dreyer, W. J. \& Anfinsen, C. B. (1959) J. Biol. Chem. 234, 2897-2900

Kohsaka, M. \& Demain, A. L. (1976) Biochem. Biophys. Res. Commun. 70, 465-473

Koppel, G. A. \& Koehler, R. E. (1973) J. Am. Chem. Soc. 95, 2403-2404

Lasky, R. A. \& Mills, A. D. (1975) Eur. J. Biochem. 56, 335-341

Miller, R. D. \& Neuss, N. (1976) J. Antibiot. 29, 902-906

O'Sullivan, J., Bleany, R. C., Huddleston, J. A. \& Abraham, E. P. (1979) Biochem. J. 184, 421-426

Turner, M. K., Farthing, J. E. \& Brewer, S. J. (1978) Biochem. J. 173, 839-850

Usher, J. J., Loder, B. \& Abraham, E. P. (1975) Biochem. J. 151, 729-739

Whitney, J. G., Brannon, D. R., Mabe, J. A. \& Wicker, K. J. (1972) Antimicrob. Agents Chemother. 1, 247-251

Woiwod, A. J. (1949) J. Gen. Microbiol. 3, 312-318

Yoshida, M., Konomi, T., Kohsaka, M., Baldwin, J. E., Herchen, S., Singh, P., Hunt, N. A. \& Demain, A. L. (1978) Proc. Natl. Acad. Sci. U.S.A. 75, 6253-6257 